\title{
The Bowling Game Can Introduce the Symbol of Numbers for Early Childhood
}

\author{
Achmadi \\ Early Childhood Program, Faculty of Teacher Training and Education University of PGRI Adi Buana, Surabaya \\ Corresponding e-mail: ajisyauqi04@yahoo.com
}

\begin{abstract}
Most parents put their children into the kindergarten in order to their children should know the symbol of numbers quickly, and they can write the number correctly. However, the parents majority are lose of this purpose. The often problems can be caused by the teacher's instruction and the child himself. One of the teacher's problems is caused by using teaching methods that do not appropriately. The learning instruction is not used by teacher variatively, so the result of the lesson is insufficient. While the children problem is the children less motivated to study the numbers. They are easily tired and bowring during they study. For example the child is difficult to recognize or to differentiate of the symbol numbers. The children could mention the numbers just memorize naturally. The Children just capable to enumerate only the sequence of the number 1 to 10 , but they also do not understand about the concept numbers. These are as issues in this study. Therefore we try to use the bowling game for introduce the symbol of numbers for early childhood. The method in this study is used based on the literature reviews about playing bowling for early childhood. The purpose of this study is describe for introducing the symbol of number for early childhood. Especially the child can enumerate the number properly. The children can show the symbol numbers correctly. The children can match the concept numbers with the symbol number. The children can write the number that's be asked with properly. Based on descriptive analysis can be concluded that the bowling game can introduce the symbol of numbers for early childhood.
\end{abstract}

Keywords: bowling game, the introduction, the numbers.

\section{INTRODUCTION}

One of the characteristics for early childhood is unique. Based on the uniqueness so the process of education for early childhood should be different with the others. Early childhood have a special life as well as the environment by themself. The world of early childhood is the play game. The play game is the best way to develop the ability for early childhood based on their competencies.

(Sujono, 2009) that the playing game directly can influence for all development needs, and can give the opportunity how to learn about themselves, the other people, and their environment. (Jamaris, 2006) said that the playing activities is an exercise to consolidate and to master the various knowledge and cognitive skills, so that the playing can function effectively for developing early childhood. Through the playing activities, especially by using the bowling game, the all mental processes can be internalised for the child himself. How to learn the number effectively for early childhood? One of the answer is by using bowling game. Because the ability to learn the numbers is one of the needed for developing early childhood. The Parents always expect that their children who has two years old until three years old must already know the symbol of numbers. The parents will happy and very proud when their children are able to enumerate and to describe the numbers at least number 1 until number 5 or 10 correctly. Because the numbers will be the basic in mathematics' program at the elementary school. In this article I would like to discuss based on my experience as a teacher for students in early childhood. The topic on this article is bowling game can introduce the symbol number for early childhood. The method is used based on the literature reviews about playing bowling for early 
childhood. When they play bowling game they feel with fun without any demand and more pleasure. So the playing bowling can be used as a media to introduce and to improve the children's numerical competences.

\section{DISCUSSION}

The introducing of number's concept and numerical concept for early childhood can be done by bowling game.

Bowling is a sport or game that is played with the rolling bowling's ball by using the hands. Bowling ball will be rolled to the pins that is consist of ten of pins. The pins have been compiled into a triangular shape when viewed from above. If all the pins were dropped in a single thrown so it is called a strike. If the pin is not dropped at once throw then given one more chance to drope it.If the second roll is not remaining pin, so it's called the spare. If after two times still the remaining pin, so it is called an open frame (missed). After that all pins will be determined to calculate for the number that is obtained in each game. The pin will be organized again as well as before to the next frame.

The bowling game can be used and modified to educate early childhood .This is also to introduce the symbol numbers for early childhood. In this study, the bowling game is modified for: the material of bowling ball, the kinds of activities, as well as the rules of the bowling game. For example bowling ball is modified with plastic material or with paper material. Pin is used from aqua bottle that is plastered with colourful of symbol numbers. The distance of throwing ball can be replaced with 1 metre or 2 metres. The ball does not to role, but also to throw to the pins intended. This game's modification will be easly the children for playing. It also makes the children very happy, fun, and free to do anywhere.

The kind of bowling game can also to introduce the numerical figures and numbers. Numerical figures and the number are kind of the essential elements in mathematics. (Yuwono and Abdullah. 2009) "Numerical figure is a sign or symbol of numbers and it is called also with numerical symbol. While the number is the abstract symbol it has contain an understanding. For example, the children faced the numerical figure of number 4 that's mean the children can call with the number four. While the number four it's mean as a symbol that consist of four something (e.g. Kind of 4 stars $* * * *)$ or other kind of the objects.

(Sudono, 2010) both are based from the theory of Piaget that shows how the mathematical concepts are formed into the child himself. The mathematics group can already be introduced for the child who has three years old. Namely the mathematics group are as (an arithmetic, a counting), the pattern and its functions, geometry, graph measurements, estimation, probability, and problem solving. To achieve the each group of the numbers it's always through three phase's emphasis, namely: a). the level of understanding of the number concept. b). the level of linking the concreate concept with the symbol of numbers. c). the level of understanding for symbol number.

(Susanto 2011) The third levels were also strengthened with the formula issued by the Indonesian Education Department: The first issue is mastery of the concepts, i.e. it's started with the dissemination of the concept or the turn of something by using the real objects, such as the introduction of color, shape of the subject, and calculate the numbers. The second issue is the phase transition that is the transition form understanding of concrete by using the real objects towards the understanding of abstraction. The third phase is the introduction of the number where once children understood something in the abstract concept, then the children may be introduced at the level of mastery concept's number by asking for children to process the addition and the subtraction through completion of a matter.

(Susanto, 2011) Specially for early childhood, that the math's skills would be developed as well as: (a) identify or enumerate the numbers; (b) say or call the sequence of the numbers; (c) calculate the objects; (d) compute the set of something with the value of the number object; (e) give the value of the number to set of objects; (f) do or complete the operation addition and subtraction by using concepts from concrete to abstract.

As this targets will be achieved through the bowling game. The child can know the numericals symbol, as well as the concept of numbers 1 until number 5 , or 10 . That is depend on the skill level and ability of the children.

\section{Organizing for playing}

Organization for the game is: this bowling activity can be done in a classical situation, in small groups, at least 5 to 8 persons. It also can be done for the individual's program in the classroom, or at the house. This game can be conducted by parents

\section{Kinds of tools are used}

The tools of bowling can modified Bowling ball can be made from plastic materials, rubber 
materials, as well as the modification of the paper materials. Pins can be modified from the cans, aqua bottles, coffer of toothpaste, or other materials that can be positioned to stand up. Each pin is given a numerical sign or symbol number, like symbol number 1 until number 5 or 10 that is plastered on its. Kind of the number is depend on the aim will be reached by the children. Bised that some various quantities of pictures are needed. Eg. : The pictures of pencil drawings, pictures of cake, pictures of kind animals, etc. These pictures will be used to compute the set of something with the value of the object number. The board and another's facilities to write the number are used in this game.

\section{The objectives are to be achieved by using this game}

By using this bowling game we can increase capability and introduce the numerical concept for our child, namely: The child can enumerate or sort the consept's number properly. The child can say or call the sequence of the number correctly. The child can calculate the obyects. The child can compute the set of something with the velue of the number to set of objects. The child can write the number it's be asked with properly

\section{Steps of the game Implementation}

The first, The children are asked to listen the explanation about the rules of the bowling game (ie: a ball throwns into the pins and the pins should fall. Throw the ball at least 3 times in 2 metres of distance. The pins does not fall can be throw again until 3 times. If any remaining pins are be ignored. The fallen pins should be responded by the way : to call the number or to say it, as well as to sort the squence the number from small to large numbers, or from large to small number, whether to compute the set numbers with the velue of number to set objects perfectly, and to write the number like each pin that was dropped, etc.).

The second, The child is asked to arrange the pin's numbers from number 1 to number 10 consecutively and randomly, ( eg. it's lined form, the shape of triangle form, or run to the rear position).

The third, Give an example how to throw the pins from certain distance and then introduce the number on the pins that are follen or not.

The forth, After the understanding of the rules, the children are asked to try for throwing pins like the already exemplified. After the ball was thrown, the children were asked to respond in accordance the aims expectetion. For example of the aims expection : a). In order to the child can enumerate correctly :
When the child had dropped the pins, like the numbers 3 and number 7, then the child should enumerate, "three and seven". If the child enumerate wrong it's means the children don't understand yet the symbol numbers. Another example, if the first , the $2 \mathrm{nd}$, and the $3 \mathrm{rd}$ throwingthat are dropped with symbol number : 4, 2, 8, 5, 1, 9, 6 , so the child is asked to sort these numbers from small to large number such as : number $1,2,4,5,6,8,9$. The child is also asked to sort from large to small number such as : number $9,8,6,5,4,2,1$. This kind of activity is as recognition of numeral form through the bowling game. b). : In order to the child can compute the set numbers with the velue of number to set objects correctly : When the child has dropped the pins number $5,10,2$, then he is asked to compute and to pair the number 5 with the five pictures of the apples, or the number 10 with the ten picture of drawing pencils, or the number 2 with the two pictures of books. If the child can compute and pair between the set number and value of number to set object's pictures, it means the child can already demonstrate to compute the concept of numbers correctly. If the child do not to do these activities, he must redo until sucsseed. c). In order to the child can calculate the numbers : The child is asked to throw a pin it has be labeled with number 7 . If the child can pick and drop the pin number 7 , it means the child can calculate and match the consept of numbers with the symbol's numbers. When this step was responded by the children corectly it's means the children can understand about between the consept's numbers and the symbol's number . d). In order to the child can write the symbol number properly: When the child has dropped the pins number 3 , number 6 , number 10 , and then the child was asked to write it on the paper or on the board that is already provided. When this issue was responded by the child corectly it's mean the child has capability to write the symbol number .

The fiveth, Each Child is welcome to try and to respond in accordance with the tasks was given. These activities must be redo until the child can fulfill the learning aims.

The sixth, Give consultation for the childrent who have difficulty in this game activities. Don't forget to give motivation by using good spocken . Beside that, it also gives the praises for each child who was tried to play bowling with good performance and precisely.

The seventh, The good situation should be kept in order the process of learning the symbol number will run properly. 
This playing steps are not absolute must be ordered such as the step's mentioned above. This activity can be done randomly. For example the activity is started with the forth step, and then the second step, and the sixth step, and so on. This kind of bowling game can be used for introducing the consept numbers for the children who have less 4 years old. This bowling activities have some efforts to the children who are learning the consep and the symbol number. As the indications are: The children can enumerate the number properly. The children can show and call the symbol numbers correctly. The children can calculate and match the consept numbers with the symbol number. The children can write a number that's be asked with properly .

\section{CONCLUSION}

The ability to know of the concept numbers for early childhood can be done through the bowling game. (Sri Ningsih 2008) writes "The children understand the concept of numbers through experience to work and to play directly with concrete objects". By playing game the child will feel happy, so that the function of the brain, and physically can developed well. In other words, beside of improving the child's cognitive ability it's also to increase the ability of physical motoric in the same time. The modification of bowling game can function to introduce for the concept numbers and numerical symbol for early childhood, for example: a. To Enumerate or to sort the consept of number precisely. $b$. To Indicate concept's number with the same symbol numbers. $c$. To match the numbers same with the symbol numbers. $d$. To writte the symbol number appropriately.

This kind bowling game can be used by early childhood teachers to introduce for the concept of numbers and numerical symbol. Because a). Bowling game is one of innovation learning process that can attract the child's interest and can make easier for child who learn to recognize the symbol of the numbers. b). Facilitating of the bowling game is not expensive. It can modified by using the useless material. c). this bowling game can be done in anywhere. Please try this bowling game to introduce and to increase the number's capability for your early childhood. I hope this article can add your experience. Thank you.

\section{ACKNOWLEDGEMENTS}

The writing of this article was partially supported by my friend's mis Isabella Hasiana and mis Aisyah, for their comments, suggestion about ideas and material, so I would like to say thank you vary mach. As well as the reviewers of this text, for their valuable contributions in this article. I also particulary thank Dr. Suhari Dean of Faculty Teacher Training and Education, University of PGRI ADI BUANA Surabaya that supports me to register in this international conference.

\section{REFERENCES}

Direktorat Pembinaan Taman kanak-kanak dan Sekolah Dasar. (2007). Pedoman Pembelajaran Permainan Berhitung Permulaan di Taman Kanak-kanak. Jakarta: Kemendiknas.

Fadlillah, M \& Khorida Lilif Mualifatu. (2013). Pendidikan Karakter Anak Usia Dini: Konsep \& Aplikasinya dalam PAUD. Jogjakarta : Ar Ruzz Media

.----------,( 2014). Edutainment Pendidikan Anak Usia Dini Menciptakan Pembelajaran Menarik, Kreatif, dan Menyenangkan. Jakarta : Kencana.

Jamaris, Martini. (2006). Perkembangan dan Pengembangan Anak Usia Taman KanakKanak. Jakarta: Grasindo.

Moeslichatoen. (2004). Metode Pengajaran di Taman Kanak-Kanak. Jakarta: PT. Rineka Cipta Papalia, Diane E., Sally Wendkos Old dan Ruth Duskin

Feldman. (2008). Human Development (Psikologi Perkembangan). Jakarta: Kencana Prenada Media Group.

Seefeldt, Carol and Barbara A. Wasik. 2008. Pendidikan Anak Usia Dini: Menyiapkan Anak Usia Tiga, Empat, dan Lima Tahun Masuk Sekolah. Jakarta: Indeks.

Siswanto, Igrea \& Lestari, Sri. (2012). Pembelajaran Atraktif dan 100 Permainan Kreatif. Yogyakarta: ANDI Yogyakarta.

Sriningsih. (2008). Pembelajaran matematika terpadu untuk Anak Usia Dini. Bandung: Pustaka Sebelas.

Sudono, Anggani. (2010). Sumber Belajar dan Alat Permainan untuk Pendidikan Anak Usia Dini . Jakarta: PT Grasindo.

Susanto, Ahmad. (2011). Perkembangan Anak Usia Dini: Pengantar Dalam Berbagai Aspeknya. Jakarta: Kencana Prenada Media Group. 


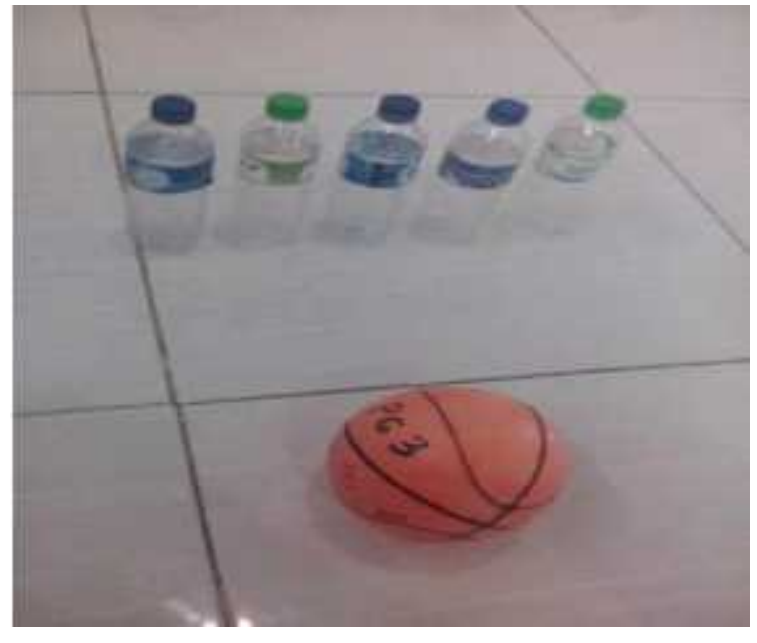

Figure 1. The Bowling Game A

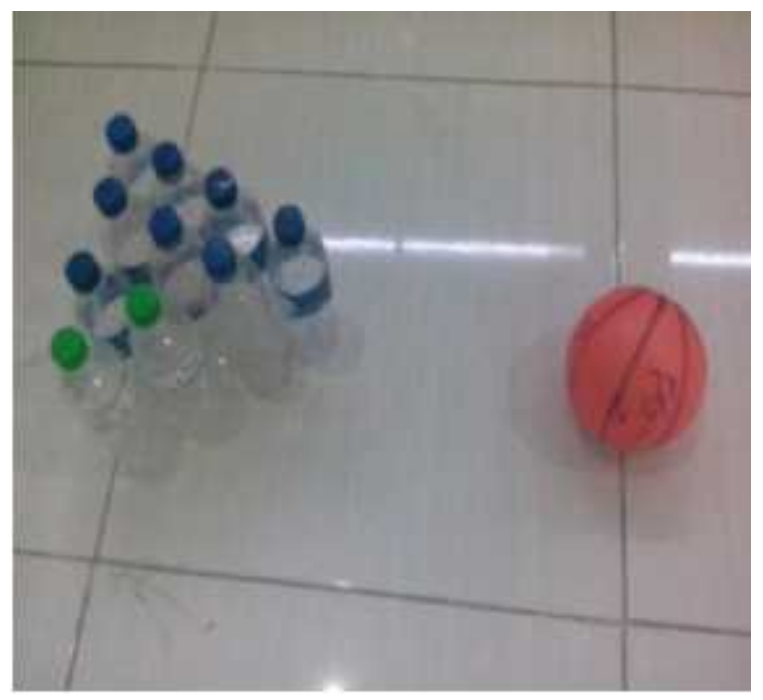

Figure 2. The Bowling Game B 